\title{
Nitrogen cycling in an estuarine upwelling system, the Ría de Arousa (NW Spain). I. Short-time-scale patterns of hydrodynamic and biogeochemical circulation
}

\author{
X. A. Alvarez-Salgado*, G. Rosón, F. F. Pérez, F. G. Figueiras, Y. Pazos \\ Instituto de Investigacións Mariñas, Consejo Superior de Investigaciones Científicas (CSIC), Eduardo Cabello 6. \\ E-36208 Vigo, Spain
}

\begin{abstract}
Nitrogen species distributions in the Ria de Arousa, NW Spain, during the upwelling season are strongly affected by the influence of shelf wind stress on water circulation. Intermittent northerly winds forced large volumes of nitrate-rich Eastern North Atlantic Central Water into the ría with a fortnightly periodicity and led to net community production maxima supported by external nitrate. Net community production in the central segment of the estuary was high (average $251 \mathrm{mg} \mathrm{m}^{-2}$ $\mathrm{d}^{-1}$ of nitrogen). However, only $20 \%$ of the total nutrient input was net taken up due to rapid water exchange. An intensive culture of hanging mussels favoured dissolved organic nitrogen formation $58 \%$ of net community production) and particulate organic nitrogen sedimentation ( $21 \%$ of net community production, or $50 \%$ of net particulate organic nitrogen formation). Consequently, more than $75 \%$ of the net dissolved +particulate organic nitrogen production was exported from the central segment, with a dissolved/particulate ratio of -3 . In addition, $40 \%$ of phytoplankton gross primary production was internally recycled by pelagic+benthic ammonifıcation in the central segment, mainly during prolonged upwelling relaxations. Low rates of particulate organic nitrogen sedimentation and low levels of conversion to dissolved organic nitrogen were observed during the development of a red tide assemblage. This appears to be field evidence of limited filtration by mussels in the presence of these organisms. A strong reversal in the residual circulation occurred in mid-October, during the transition from northerly to southerly winds. Ammonium released from the estuarine sediments, at a high average net rate of $162 \mathrm{mg} \mathrm{N} \mathrm{m}^{-2} \mathrm{~d}^{-1}$, was exported towards the shelf.
\end{abstract}

KEY WORDS: Nitrogen speciation - Rías Baixas (NW Spain) - Upwelling/downwelling · Mussel rafts

\section{INTRODUCTION}

Estuarine and coastal areas play a major role in global biogeochemical cycles, since biological, chemical and sedimentary processes are greatly enhanced at these ocean margins (Wroblewski \& Hoffmann 1989, Mantoura et al. 1991). These cycles are especially intensified in wind-driven upwelling zones, where the

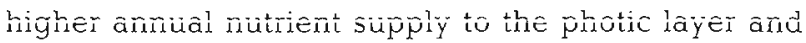

•E-mail:xsalgado@nautilus.iim.csic.es the characteristic circulation patterns control biogeochemical processes (Barber \& Smith 1981). Complexity of nitrogen biogeochemistry in the marine environment arises from the number of chemical species in different oxidation levels and aggregation states, and from the biogeochemical processes involved (Carpenter \& Capone 1983, Wada \& Hattori 1991). In addition, nitrogen is usually the limiting element for net primary

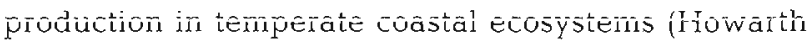
1988, Vitousek \& Howarth 1991).

The Spanish Rías Baixas are estuary-like coastal inlets situated along the northern boundary $\left(42^{\circ}\right.$ to 
$43^{\circ} \mathrm{N}$ ) of the NW Africa upwelling system, which extends from $10^{\circ}$ to $44^{\circ} \mathrm{N}$ (Wooster et al. 1976). The density gradients along these embayments are strongly modified by shelf wind stress (Blanton et al. 1984). Northerly winds cause Eastern. North Atlantic Central Water, ENAW, to upwell over the shelf (Fraga 1981) and enhance the 2 -layer residual circulation pattern (Prego \& Fraga 1992). Southerly winds, however, generate downwelling, thus forcing shelf surface waters to move towards the rias. In this situation, the balance between river discharge and shelf wind stress will ultimately determine the flow of water, giving rise to a reversal in the positive circulation during strong downwelling events.

From May to October, the prevailing northerly winds produce a 1 to $2 \mathrm{wk}$ stress/relaxation cycle (Blanton et al. 1987), which is the main controller of estuarine circulation, due to river discharge being rather low during summer (Roson et al. 1991). Upwelling lifts the cold, nutrient-rich ENAW from 150 to $200 \mathrm{~m}$ depth to above $50 \mathrm{~m}$ (Alvarez-Salgado et al. 1993), shallow enough to enter the rías by means of the enhanced residual circulation. This fertilization by upwelling results in high rates of phytoplankton photosynthesis. Prego (1993a), using a steady-state box model method, estimated the mean annual primary production in the central part of the adjacent Ría de Vigo to be about $790 \mathrm{mg} \mathrm{C} \mathrm{m} \mathrm{m}^{-2} \mathrm{~d}^{-1}$. This value coincides with that obtained by Fraga (1976) from ${ }^{14} \mathrm{C}$ measurements, and it is close to the average proposed by Boynton et al. (1982) for upwelling-affected ecosystems: $300 \mathrm{~g} \mathrm{~m}^{-2} \mathrm{yr}^{-1}$ or $820 \mathrm{mg} \mathrm{m}^{-2} \mathrm{~d}^{-1}$ Average summer primary production is almost double the annual mean daily value (Fraga 1976), and it increases more than 3-fold in upwelling conditions (Prego 1993a). In the Ría de Arousa it is probably higher, as this ecosystem is more affected by shelf wind stress (Figueiras \& Pazos 1991), according to predictions from the vorticity theory (Blanton et al. 1984)

While the singularity of this coastal inlet as a hydrodynamic system is due to the influence of winddriven upwelling on the residual circulation, nitrogen biogeochemistry must also be strongly affected by the intensive hanging mussel culture here: 2400 rafts producing ca $100000 \mathrm{t} \mathrm{yr}^{-1}$ (total wet weight) of edible mussels (Navarro et al. 1991), which represents enough biomass to have a clear impact on the whole ecosystem (Smaal \& Prins 1993). Although zooplankton can sometimes compete with bivalves (Hanson et al. 1986), mussels are the dominant herbivore in the Ría de Arousa (Tenore \& González 1975). Hanging mussels concentrate phytoplankton biomass by filtration at high rates, but show low trophic web efficiency (5\% according to Cabanas et al. 1979). They release large amounts of ammonium into the water column (2 to $3 \mu \mathrm{mol} \mathrm{g}^{-1}$ mussel $\mathrm{h}^{-1}$; Smaal \& Prins 1993), which is recycled to nitrogen-limited phytoplankton populations. On the other hand, a large increase in dissolved organic nitrogen (DON) can be expected if cell lysis of filtered but not completely ingested, digested or absorbed phytoplankton takes place, according to the hypothesis of Jumars et al (1989) regarding biogenesis of dissolved organic matter (DOM). In addition, excretion of faecal material that sinks faster than phytoplankton cells or detritus also occurs, increasing the sedimentalion rates (Kaspar et al. 1985, Rodhouse \& Roden 1987). Faecal material supports a large community of detritivores over the hanging ropes and the bottom biodeposits (Tenore et al. 1982), where an intense benthic remineralization and subsequent release of inorganic nitrogen to the water column, mainly as ammonium, occurs (Baudinet et al. 1990).

General studies have already been conducted to establish interseasonal differences in the nitrogen cycle for the Rías Baixas (Fraga 1967, Cabanas et al. 1983, Prego 1994). These studies used sampling intervals that greatly exceed the variability imposed by upwelling on the hydrographic regime of the rías.

The present work focuses on the seasonality of $\mathrm{NH}_{4}{ }^{+}$, $\mathrm{NO}_{2}{ }^{-}, \mathrm{NO}_{3}{ }^{-}$and particulate organic nitrogen (PON) profiles at a reference station in the middle of the Ria de Arousa, from May to October 1989. Fluxes and net budgets of nitrogen species were calculated with an improved 2-dimensional kinematic box model (Rosón et al. in press) which evaluates the relative importance of water circculation and biogeochemical processes for the observed distributions. New and recycled production were distinguished by comparing phytoplankton gross primary production (GPP), calculated from P-I curve parameters, and net community production (NCP) estimated with the box model.

In the companion paper (Alvarez-Salgado et al. 1996 - this issue), spatial differences in the hydrodynamics and biogeochemistry of nitrogen species in this ría are considered for different hygrographic regimes that prevail here.

\section{MATERIALS AND METHODS}

Hydrographic sampling was carried out twice a week in the Ría de Arousa (Fig. 1), from May 1.2 to October 30, 1989. Ten stations were occupied and water samples were drawn from 5 to 7 depths (depending on the bathymetry) with 5 l Niskin bottles equipped with reversing thermometers.

Chemical analyses. Salinity was determined from conductivity measurements (UNESCO 1983), using an 

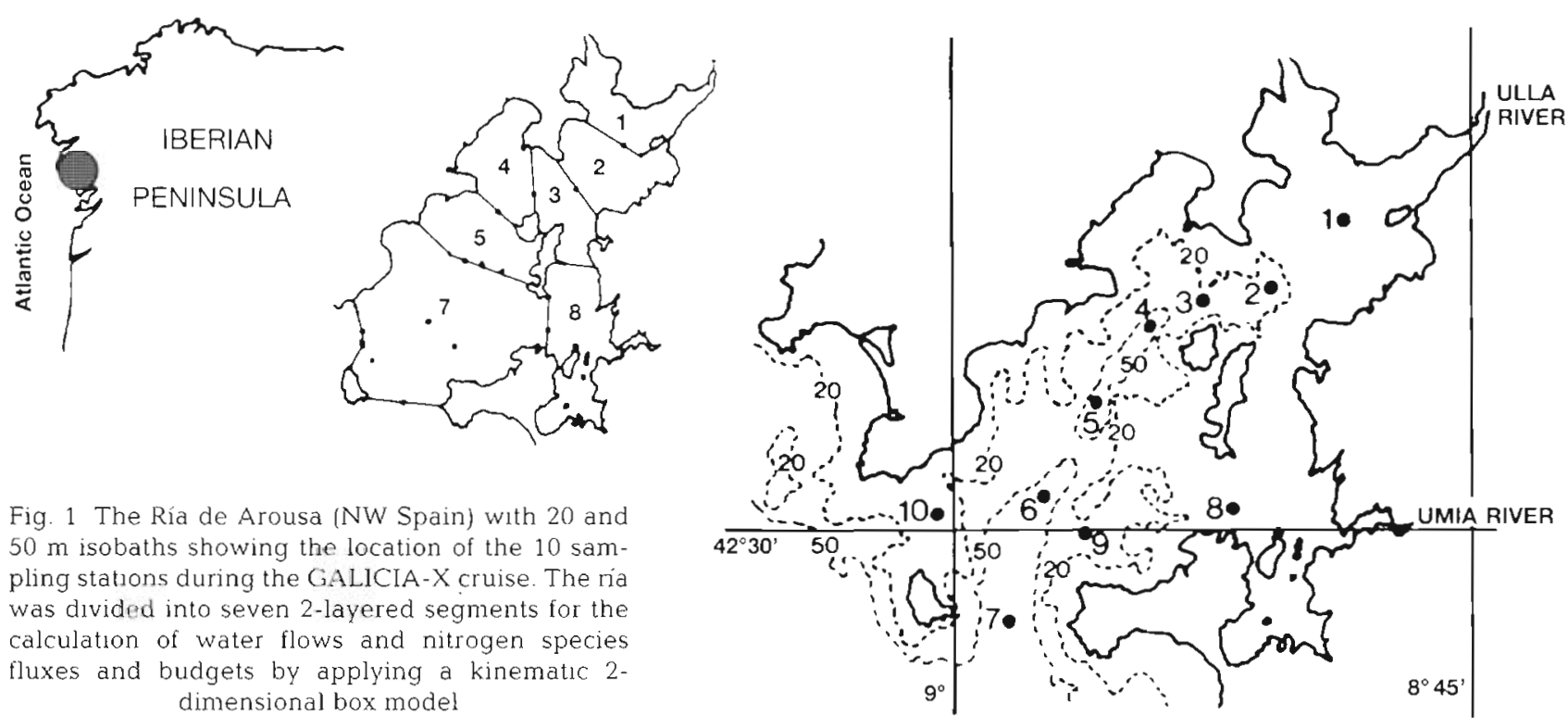

Fig. 1 The Ria de Arousa (NW Spain) with 20 and $50 \mathrm{~m}$ isobaths showing the location of the 10 sampling stations during the GALICIA-X cruise. The ria was divided into seven 2 -layered segments for the calculation of water flows and nitrogen species tluxes and budgets by applying a kinematic 2dimensional box model

AUTOSAL $8400 \mathrm{~A}$ with a precision of \pm 0.003 psu. Nutrients were analysed on board by segmented flow analysis with a Technicon AAII according to Hansen \& Grasshoff (1983), with some small modifications (Mouriño \& Fraga 1985, Alvarez-Salgado et al. 1992) The precision was $\pm 0.02 \mu \mathrm{mol} \mathrm{kg}^{-1}$ for nitrite, \pm 0.1 $\mu$ mol $\mathrm{kg}^{-1}$ for nitrate, $\pm 0.05 \mu \mathrm{mol} \mathrm{kg}{ }^{-1}$ for ammonium and silicate, and $\pm 0.01 \mu \mathrm{mol} \mathrm{kg}^{-1}$ for phosphate. Chlorophyll a was measured fluorometrically, using a Turner Designs $10000 \mathrm{R}$ fluorometer, after $90 \%$ acetone extraction (Yentsch \& Menzel 1963). The precision was $\pm 0.05 \mathrm{Mg} \mathrm{l}^{-1}$. PON, collected over Whatman GF/F filters, was analysed in a PE2400 CHN elemental analyser with a precision of $\pm 0.04 \mu \mathrm{mol} \mathrm{kg-1}$ Particulate organic phosphorus (POP) was determined by $\mathrm{H}_{2} \mathrm{SO}_{4} / \mathrm{HClO}_{4}$ digestion, at $220^{\circ} \mathrm{C}$, of particulate organic matter (POM) collected over whatman GF/F filters. The phosphoric acid produced was analysed. after neutralisation, using the segmented flow analytical procedure for phosphate. The precision for the entire analysis was $\pm 0.01 \mu \mathrm{mol} \mathrm{kg}^{-1}$ POM measurements were begun on June 8 (survey 5). Consequently. the biogeochemical budget for nitrogen could not be traced until that date.

Upwelling Index. The Upwelling Index $\left(I_{w}\right)$, a rough estimate of the amount of water upwelled per second per kilometer of coast, was calculated according to Wooster et al. (1976):

$$
I_{w}=\frac{\rho_{\mathrm{a}} \cdot C \cdot|\vec{V}|}{f \cdot \rho} V_{N}
$$

where $\hat{p}_{\mathrm{d}}$ is the density of air, $1.22 \mathrm{~kg} \mathrm{~m} \mathrm{~min}^{-3}$ at $15^{\circ} \mathrm{C}, C$ is an empirical drag coefficient (dimensionless), $1.3 \times 10^{3}$ according to Hidy (1972); $f$ is the Coriolis parameter, $9.946 \times 10^{-5} 5^{-1}$ at $43^{\circ}$ latitude; $\rho$ is the density of sea- water, $-1025 \mathrm{~kg} \mathrm{~m}^{-3} ;|\vec{V}|$ is wind speed; and $V_{\mathrm{N}}$ is the north component of wind speed. Wind data were taken at the Cape Finisterre Meteorological Observatory.

Box model of biogeochemical circulation. Residual flows in the ría were taken from Rosón et al. (in press). These were obtained from salinity and temperature distributions, using an improved 2-dimensional kinematic non-steady-state mass/heat weighted box model. The Ría de Arousa was divided into 7 boxes (Fig. 1), whose geometric characteristics are summarised in Table 1. For the upper $\left(Q_{X}\right)$ and lower $\left(Q_{x_{0}}\right)$ layers, the opposing horizontal residual flows as well as the vertical exchange between the layers by advection $\left(Q_{7}\right)$ and turbulent diffusion $\left(M_{Z}\right)$ were obtained (Fig. 2). The geometry of the ría, an input to the box model, permits estimation of the averaged horizontal $\left(v_{x 0}, v_{x}\right)$ and vertical $\left(v_{z}\right)$ residual velocity field and the velocity of vertical mixing $\left(V_{M}\right)$. The latter can be related to an averaged-over-box vertical diffusion coefficient $\left(k_{z}\right)$ by means of the simple equation $k_{z}=$ $v_{M}(Z / 2)$, with $Z$ being the mean depth of the box.

Table 1. Geometric characteristics of each box into which the Ría de Arousa was segmented

\begin{tabular}{|ccccc|}
\hline Box & $\begin{array}{c}\text { Volume } \\
\left(10^{-3} \mathrm{~km}^{3}\right)\end{array}$ & $\begin{array}{c}\text { Surface area } \\
\left(\mathrm{km}^{2}\right)\end{array}$ & $\begin{array}{c}\text { Length } \\
(\mathrm{km})\end{array}$ & $\begin{array}{c}\text { Depth } \\
(\mathrm{m})\end{array}$ \\
\hline 1 & 229 & 28 & 4.1 & 8 \\
2 & 229 & 23 & 3.4 & 10 \\
3 & 297 & 18 & 2.6 & 17 \\
4 & 488 & 24 & 31 & 20 \\
5 & 651 & 23 & 6.8 & 28 \\
7 & 2538 & 95 & 9.7 & 27 \\
8 & 109 & 29 & 6.4 & 4 \\
\hline
\end{tabular}




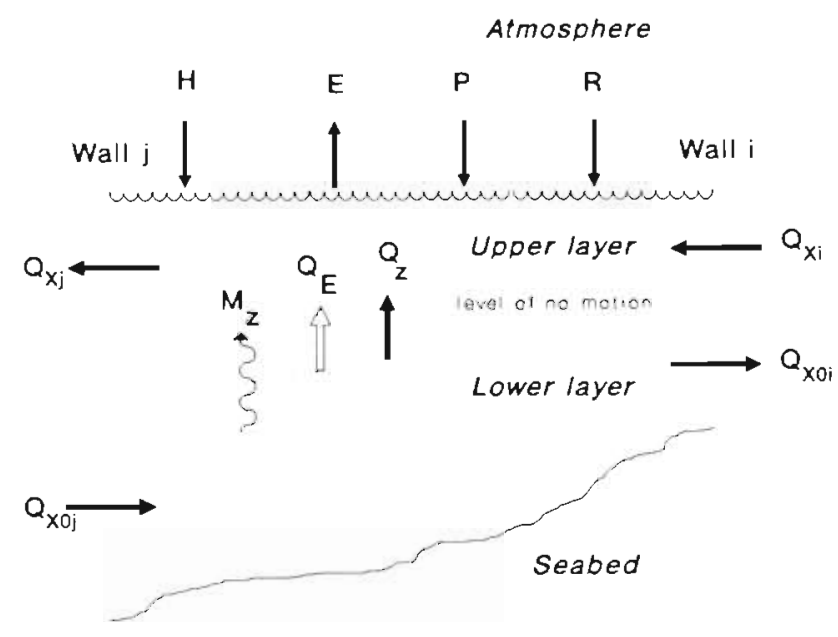

Fig. 2. Terms in the water budget of the 2 layers of every box in which the Ría de Arousa was segmented. $Q_{X_{1}}$ and $Q_{X_{j}}$ : inward and outward convective flows to the upper layer of the box; $Q_{\times 01}$ and $Q_{\times 01}$ : outward and inward convective flows to the lower layer; $Q_{2}$ : upward convective flow from the lower to the upper layer; $Q_{E}$ : entrainment flow; $M_{z}$ : vertical turbulent diffusive flow; $H$ : heat gain from the atmosphere; $P$ : precipitation; E: evaporation; R: continental runoff. After Rosón et al. (in press)

In each layer of each box, the net budget of inputs and outputs $(\mathrm{i}-0)$ for a given nitrogen. form $(N)$ results from hydrodynamic accumulation, $\partial(N \cdot V) / \partial t$, and biogeochemical processes, $\delta N$ :

$$
\mathrm{i}-\mathrm{o}=\frac{\partial(N \cdot V)}{\partial t}-\delta N=\sum_{i} Q_{i} \cdot N_{i}+M_{z} \cdot d N_{\mathrm{L}}+R \cdot N_{\mathrm{R}}
$$

where $t$ is time; $Q_{i}$ is volume $\left(\mathrm{m}^{3} \mathrm{~s}^{-1}\right)$ and $N_{1}$ is concentration of $N\left(\mathrm{~mol} \mathrm{~m}^{-3}\right.$ ) carried by the convective flow $i_{i}$ $d N_{L}$ is the difference in $N$ concentration between the upper and lower layer; $R$ and $N_{R}$ represent water flow and concentration of $\mathrm{N}$ in continental runoff to the box (obviously only applicable to the upper layer); and $V$ is the volume of the layer $\left(\mathrm{m}^{3}\right)$. Positive values of $\delta N$ indicate a net increase of $\mathrm{N}$ by biogeochemical processes.

The net budget for $N$ between surveys $j-1$ and $j$, $\mathrm{I}-\mathrm{O}$, can be obtained by integrating Eq. (2) from $t_{j-1}$ to $t_{j}$ :

$$
\begin{aligned}
\mathrm{I}-\mathrm{O} & =N_{i_{j}} V_{t_{j}}-N_{t_{j-1}} \cdot V_{t_{j-1}}-\Delta N \\
& =\int_{t_{i-1}}^{t_{1}} \sum_{1} Q_{i} \cdot N_{1} \cdot \mathrm{d} t+\int_{i_{i-1}}^{i_{1}} M_{2} \cdot d N_{\mathrm{L}} \mathrm{d} t+\int_{i_{i-1}}^{t_{1}} R \cdot N_{\mathrm{R}} \cdot \mathrm{d} t
\end{aligned}
$$

where $\Delta N$ is the biogeochemical budget $(\delta N)$ integrated between $t_{j-1}$ and $t_{j}$.

If a linear change of thermohaline properties and river volume is assumed between $t_{j-1}$ and $t_{j}$ a quasiparabolic variation of computed residual flows, $Q_{1}$ occurs (Rosón et al. in press) In addition, if $N_{1}$ and $N_{\mathrm{R}}$ also vary linearly between $t_{j-1}$ and $t_{j}$ the flux of $\mathrm{N}$ carried by $Q_{1}$ from $t_{j-1}$ to $t_{j}$ can simply be calculated as:

$$
\begin{aligned}
F_{1} & =\int_{t_{j-t}}^{t_{1}} Q_{1} \cdot N_{1} \cdot \mathrm{d} t \\
& =\frac{1}{6}\left[Q_{i, t_{j-1}} \cdot N_{i_{j-1}}+2 Q_{i_{i} t_{m}}\left(N_{i_{j-1}}+N_{t_{j}}\right)+Q_{i, t_{j}} \cdot N_{t_{j}}\right]
\end{aligned}
$$

where $Q_{1, t_{m}}$ is the residual flow $i$ at $t=0.5\left(t_{1}+t_{j-1}\right)$, calculated by solving Eq. (3) for the thermohaline properties. The same kind of calculation can be applied to obtain the flux of $N$ carried by $M_{z}$ from $t_{j-1}$ to $t_{\text {. }}$.

$\triangle N$ for DIN, DON and PON $(\triangle D I N, \triangle D O N$ and $\triangle \mathrm{PON}$ respectively) can be obtained by solving Eq. (3) for each nitrogen pool. $-\Delta \mathrm{DIN} /\left(t_{j}-t_{t_{-}}\right)$is the averaged net rate at which uptake of DIN occurs by the community of organisms. It represents the net community production (NCP) of the ecosystem, i.e. the gross primary production minus the respiration of autotrophs and all heterotrophs (Platt et al. 1989) inside the volume considered during the 3 to $4 \mathrm{~d}$ between 2 consecutive surveys. $\triangle D O N$ results from the balance between exudation, excretion and cell lysis on the one hand, and uptake by both autotrophic and, mainly, heterotrophic populations on the other. $\triangle P O N$ is affected by settlement from the upper to the lower layer and by deposition over the bottom:

$$
\triangle \mathrm{PON}=-\Delta \mathrm{DIN}-\triangle \mathrm{DON}-E_{\mathrm{N}}
$$

where $E_{\mathrm{N}}$ includes: net PON removal by large herbivores, mainly hanging mussels $(G)$; net PON sedimentation $(S)$; and net inorganic nitrogen uptake by macrophytes $\left(\mu_{\mathrm{M}}\right)$ :

$$
E_{\mathrm{N}}=G+S+\mu_{\mathrm{M}}
$$

Carbon content in mussel flesh represents about $2.5 \%$ of total wet weight (Tenore et al. 1982, Pérez Camacho \& González 1984). Assuming a C/N ratio of 6.8 (Tenore et al. 1982), an annual extraction of 100000 $t$ led to a net removal of only $\sim 5 \mathrm{mg} \mathrm{m}^{-2} \mathrm{~d}^{-1}$ of nitrogen by herbivores ( $G$ ). DIN uptake by macrophytes was estimated to be negligible. Phytoplankton production in the rías is more than 10-fold higher than macrophyte production (Varela et al. 1984) and nitrogen only represents $2 \%$ of macrophyte total biomass (Niell \& Mouriño 1981). Consequently, net PON settlement was the main term in $E_{\mathrm{N}}$.

Box model applications to estuaries usually assume steady-state conditions (Taft et al. 1978, Officer 1980 , Smith \& Veeh 1989). In such cases, the net budget (I O) would equal the biogeochemical activity $(\Delta N)$, as the concentration of $N$ is assumed to remain constant inside the box. This assumption could result in large errors if appreciable hydrographic changes occur over short time intervals. The variability imposed by upwelling on the hydrographic regime of the rias justi- 
fies the need for a survey interval of 3 to $4 \mathrm{~d}$, and the development of a non-steady-state box model similar to that used by Matsukawa \& Suzuki (1985) and Suzuki \& Matsukawa (1987) for 2 bays in Japan. Moreover, changes in the depth level of non-horizontal motion affect the size of both layers and contribute to vertical transport of $\mathrm{N}$ by a mechanism of 'entrainment' of layers $(N \cdot \mathrm{d} V / \mathrm{d} t)$, not accounted for by steady-state box. models, in addition to convection and turbulent diffusion. The entrainment flow $Q_{E}$ (Fig. 2) can be calculated as $\mathrm{d} V / \mathrm{d} t$

$$
N \frac{\mathrm{d} V}{\mathrm{~d} t}=\frac{\mathrm{d}(N \cdot V)}{\mathrm{d} t}-V \frac{\mathrm{d} N}{\mathrm{~d} t}
$$

This model defines the role of the rías as nutrient-salt traps, evaluates the relative importance of physical and biogeochemical processes during the upwelling season, and constitutes a significant improvement over the steady-state box models previously used in these coastal embayments (Otto 1975, Prego \& Fraga 1992).

$\triangle \mathrm{DON}$ and phosphorus biogeochemistry. DON concentration was not measured, due to the lack of a reliable method at the time of sampling (e.g Hedges \& Lee 1993). Therefore, it was necessary to resort to the phosphorus cycle in order to close the nitrogen cycle.

The main characteristic of the biogeochemical cycle of phosphorus is that the element retains the oxidation state +5: as phosphate $\left(\mathrm{HPO}_{4}{ }^{2}\right)$ in the DIP pool, and as phosphoric ester in the DOP and POP pools. Since exchange between organic and inorganic forms occurs by means of hydrolysis/esterification reactions, phosphorus shows faster recycling times than other nutrient salts (Garber 1984). The PIP pool is constituted by phosphate stored inside phytoplankton cells which can represent as much as $40 \%$ of cellular phosphorus (Miyata \& Hattori 1986), and that which is adsorbed onto suspended matter. Phosphorus collected over Whatman GF/F filters is POP + PIP, i.e. total particulate phosphorus (TPP). In contrast, the DOP concentration is extremely low in the Rías Baixas, as reported by Ríos (1992) and Prego (1993b). Both authors used a combined persulphate-UV oxidation technique similar to that successfully performed by Ridal \& Moore (1990). Consequently:

$$
\triangle \mathrm{TPP}=-\Delta \mathrm{DIP}-E_{\mathrm{P}}
$$

where $\triangle T$ PP and $\triangle$ DIP are obtained by solving Eq. (3) for the phosphorus species. $E_{\mathrm{P}}$ can be estimated from Eq. (8) and, from the daily averaged PON/TPP ratio, we obtain $E_{\mathrm{N}}$. Then $\triangle D O N$ can be calculated as:

$$
\Delta \mathrm{DON}=-\Delta \mathrm{DIN}-\Delta \mathrm{PON}-[\mathrm{PON}] /[\mathrm{TPP}] \cdot E_{\mathrm{P}}
$$

Estimation of gross primary production. From July 10 to September 14 , water samples from 5 depths (0 to $40 \mathrm{~m}$ ) at $\operatorname{Stn} 4$ were incubated in $70 \mathrm{ml}$ disposable plas- tic tissue-culture bottles with $\mathrm{Na}_{2}{ }^{14} \mathrm{CO}_{3}$. Incubations were carried out at 7 light intensities for $2 \mathrm{~h}$. Consequently, phytoplankton gross primary production (GPP) can be estimated at each light intensity, as these short incubations did not account for respiration of the inoculated ${ }^{14} \mathrm{C}$

Photosynthesis-irradiance $(P-I)$ curves were obtained by fitting the experimental data to the classical inverse exponential equation (Platt 1981). A rough estimation of the $24 \mathrm{~h}$ gross primary production at each sampling depth $\left(\mathrm{GPP}_{z}\right)$ can be calculated as follows (Platt et al. 1990):

$$
G P_{Z}=P_{\max }[\operatorname{chl} a] \cdot D \int_{0}^{1}\left(1-\mathrm{e}^{-I_{0}^{m / 2} e^{-\lambda /} \cdot \sin (\pi \cdot x) / I_{k}}\right) \cdot d x
$$

where $P_{\max }\left(\mathrm{mg} \mathrm{C} \mathrm{mg}^{-1} \mathrm{chl} \mathrm{a} \mathrm{h}^{-1}\right)$ and $I_{k}\left(\mu \mathrm{E} \mathrm{m} \mathrm{m}^{-2} \mathrm{~s}^{-1}\right)$ are the $P$ - $I$ curve parameters (Platt 1981); [chla] is the $24 \mathrm{~h}$ averaged chl a concentration ( $\mathrm{mg} \mathrm{m}^{-3}$ ); $D$ is daylength (h); $I_{0}{ }^{\mathrm{m}}$ is the underwater light intensity at $0 \mathrm{~m}$ depth at 12:00 h GMT $\left(\mu \mathrm{E} \mathrm{m}^{-2} \mathrm{~s}^{-1}\right) ; k$ is the coefficient of light attenuation with depth $\left(\mathrm{m}^{-1}\right)$; and $x$ is a fraction of 1 day.

To estimate $\mathrm{GPP}_{z}$, it was necessary to assume that $P_{\text {max }}, I_{k}$ and [chl a] remain constant during the integration period $(24 \mathrm{~h})$. $I_{0}^{\mathrm{m}}$ was estimated using Mosby's formula (Dietrich et al. 1980). The irradiance value obtained was reduced roughly by $45 \%$, so that we considered only the range of photosynthetically active radiation (PAR; Baker \& Frouin 1987). Finally, light attenuation across the air-sea interface (i.e. the ratio $I_{0}{ }^{-} / I_{0}{ }^{+}$) was obtained to estimate $I_{0}{ }^{\mathrm{m}} . I_{0}{ }^{+}$is the overwater light intensity, as measured with a $2 \pi$ LICOR sensor at the time when samplings occurred. The sampling time changed from day to day, as the station was always occupied at the same tidal stage. $I_{0}^{-}$is the underwater light intensity at $0 \mathrm{~m}$, calculated by adjusting the PAR profile, obtained with a $2 \pi$ LICOR underwater sensor at sampling time, to the classical equation of light attenuation with depth $\left(I=I_{0}{ }^{-} e^{-k z}\right)$.

Consequently, GPP $z$ as calculated from Eq. (10) cannot be used for quantitative purposes, but the qualitative information that can be obtained from this estimation must not be dismissed. The average water column GPP (mg m $\mathrm{m}^{-2} \mathrm{~d}^{-1}$ ) was estimated by integrating $\mathrm{GPP}_{z}$ with depth.

\section{RESULTS AND DISCUSSION}

\section{Circulation versus stratification in the ría}

Tho tomporal hydrographic variability and the rosid ual flow patterns in the Ría de Arousa during the period studied have been thoroughly described by Rosón et al. (1995). Patterns of density ( $\rho$ ) anomaly, $\gamma=$ 

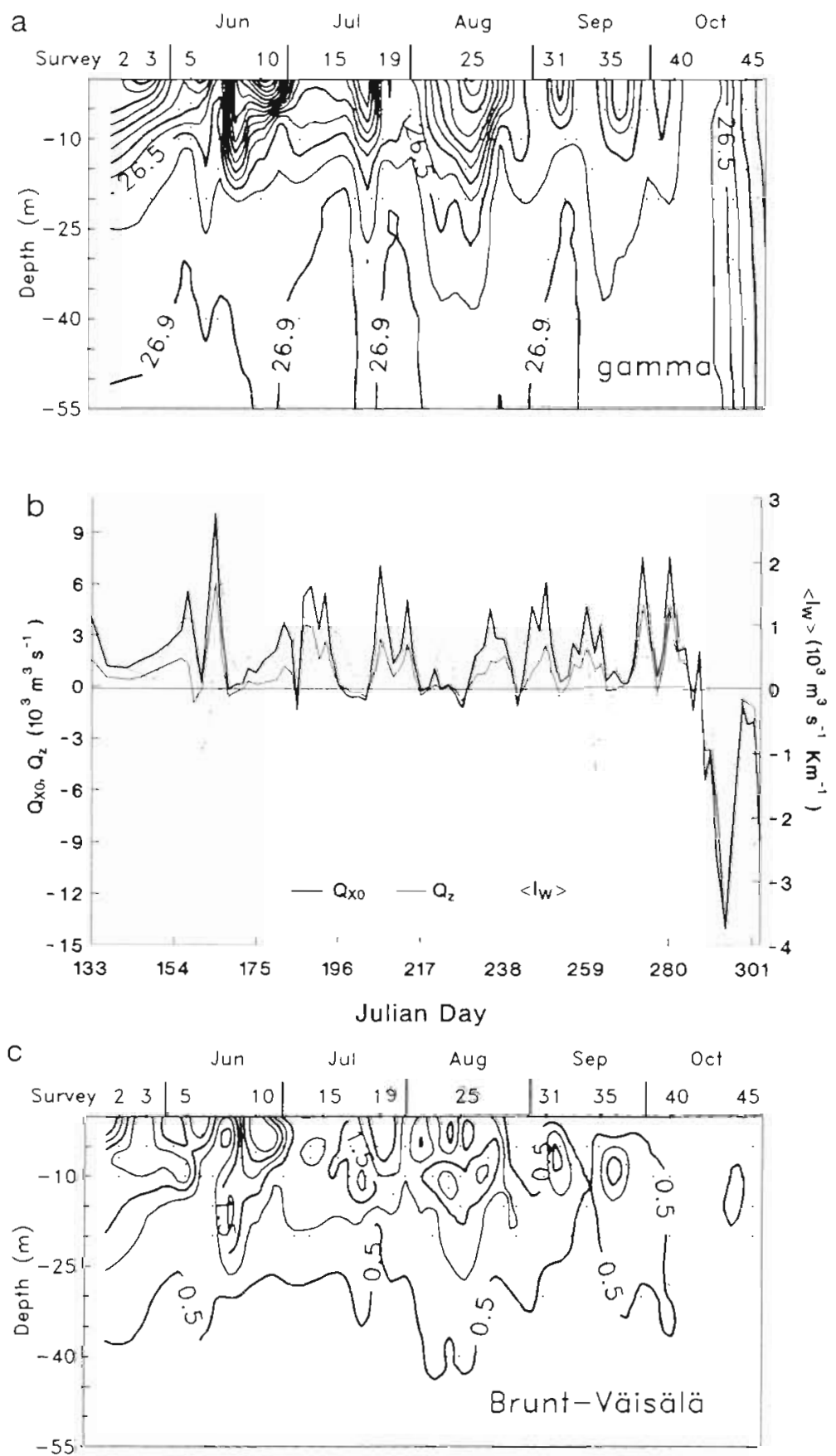

Fig. 3. Time course of (a) y profile; $(b)<I_{w}>$ in $\mathrm{m}^{3} \mathrm{~s}^{-1} \mathrm{~km}^{-1}$, inward $\left(Q_{x 0}\right)$ and upward $\left(Q_{z}\right)$ convective flows in $\mathrm{m}^{3} \mathrm{~s}^{-1}$ and (c) Brunt-Väisalä frequency profile in $\min ^{-1}$ at $\operatorname{Stn} 4$. Negative values of $\left\langle I_{w}\right\rangle$ indicate downwelling successive inflows and outflows of ENAW into the ría, driven by shelf wind stress (Fig. 3b). However, pure ENAW was not usually found at the bottom of the reference Stn 4 because it mixes rapidly with other water bodies when it enters the ría. Over the period studied, the depth level of non-horizontal motion ranged from 27 to $7 \mathrm{~m}, 15 \mathrm{~m}$ being the average. Horizontal and vertical residual flows from the box model were in clear agreement with the previous qualitative description. During upwelling events (maximal $I_{\mathrm{w}}$ values), the 26.7 and 26.9 isopycnals rose to shallower levels, and higher currents were computed. In contrast, upwelling relaxations were characterised by a blockage or even a weak reversal of the estuarine circulation. Towards the end of the study period, on October 15 , residual currents indicated a reversal of the flow inside the ría related to a strong downwelling event in the shelf (Alvarez-Salgado et al. 1993). The warmer and less saline shelf surface water entered the ria, as can be observed in the $\gamma$ profile at Stn 4 (Fig. 3a). In this hydrographic situation, the use of a steady-state box model would lead to erroneous estimated flows.

$I_{\mathrm{w}}$ was clearly correlated with the vertical displacements of the isopycnals and the computed residual currents. The best fit between $I_{w}$ and $Q_{x_{0}}\left(r^{2}=0.47\right)$ was obtained for geostrophic winds averaged from $72 \mathrm{~h}$ before every sampling date, $\left\langle I_{w}\right\rangle$. Although the influence of non-local winds in residual currents has been reported for some fjords and temperate estuaries (Carter et al. 1979, Wroblewski \& Hoffmann 1989), it is unusual that half of the total variance in estuarine circulation is controlled by shelf wind stress, as occurs in the Ria de Arousa. Vertical and horizonta]. convective flows are strongly coupled $\left(\mathrm{r}^{2}=0.90\right)$ and the $Q_{Z}: Q_{X 0}$ ratio is high $(\sim 0.7)$. This behaviour is likely due to the abrupt change in bathymetry surrounding the station (Fig. 1)

Changes in the Brunt-Väisälä frequency, $N$, over time showed the formation of a pyc$p(s, t, 0)-1000$ (where $s=$ salinity, $t=$ temperature, $0=$ atmospheric pressure; UNESCO 1985) distribution in the lower layer at the reference station (Stn 4) were mainly controlled by wind-driven upwelling. The succession of peaks and valleys observed in the 26.7 isoline, and the intermittent advection of water with density greater than 26.9 (Fig. 3a), served to trace the nocline at $\sim 10 \mathrm{~m}$ depth during upwelling relaxations (Fig. 3c), leading to stability maxima during Surveys $3,10,18,25,33$ and 37 During upwelling events this density boundary was eroded or even broken, resulting in homogenization (Survey 30, September 4). From mid-October, the downwelling was characterised by strong vertical mixing. Water column stabil- 


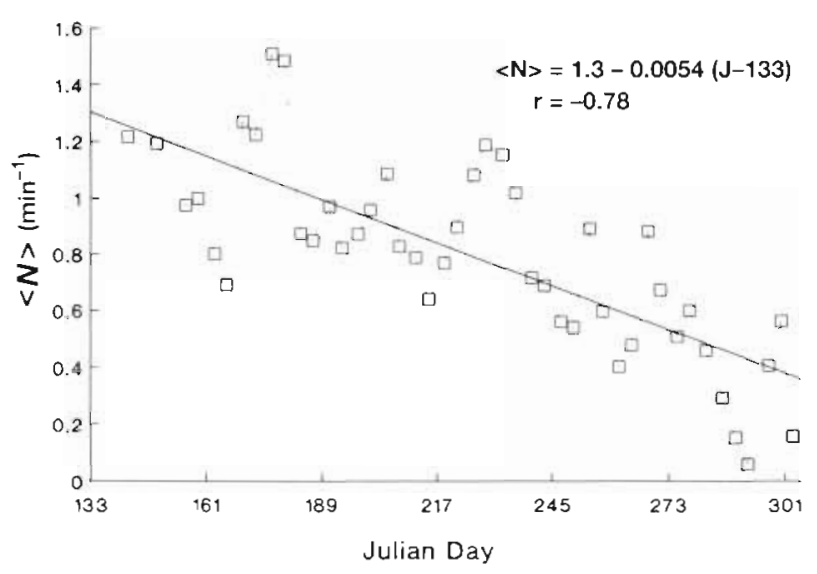

Fig. 4. Time course of the depth-averaged Brunt-Väisäla frequency $\langle\langle N\rangle)$ in $\mathrm{min}^{-1}$ at $\operatorname{Stn} 4$. This was calculated as $<N>=\left\{4 g\left(\rho_{1}-\rho_{u}\right) /\left(\left(\rho_{1}+\rho_{1}\right) Z\right]\right\}^{1 / 2}$ where $\rho_{1}$ and $\rho_{u}$ are the mean density of the upper and lower layer calculated from the box model; $Z$ is the depth at $\operatorname{Stn} 4$; and $g$ is the gravity acceleration

ity tended to decrease linearly with time at an average rate of $5.4 \times 10^{-3} \mathrm{~min}^{-1} \mathrm{~d}^{-1}$, which explains $61 \%$ of the variability observed in the depth-averaged BruntVäisälä frequency, $\langle N>$ (Fig 4). This is related to the convergence between upper and lower layer densities, owing to the decrease in river discharge and in the net heat gained from the atmosphere during the study period. The progressive decrease in density of the subtropical ENAW that arrived off NW Spain during 1989 (Alvarez-Salgado et al. 1993) tended to diminish lower layer density. The succession of upwelling/relaxation events, with a periodicity of $14 \pm$ $4 \mathrm{~d}$, was superimposed over this linear tendency observed in $\langle N\rangle$.

The stratification-circulation diagram in Fig. 5 shows all the situations found in the Ría de Arousa during the study period, in a hydrographic matrix defined by the

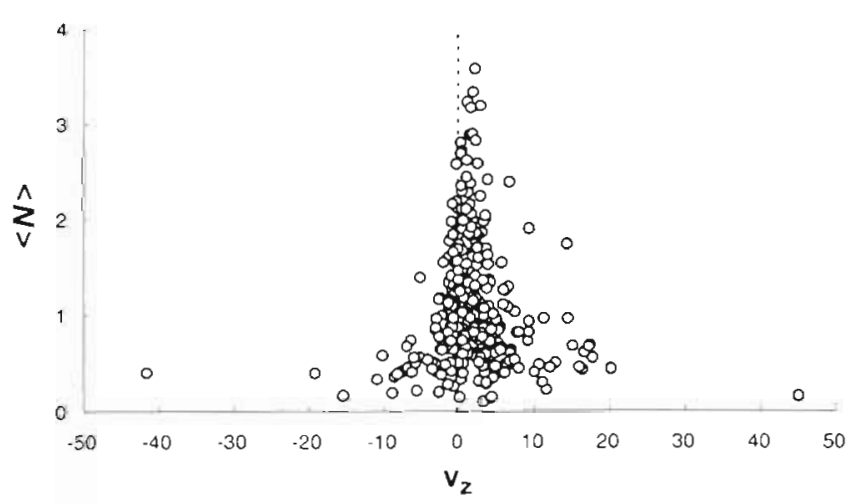

Fig. 5. Stratification-circulation diagram: upward velocity $(v$, in $\mathrm{m} \mathrm{d}^{-1}$, versus depth-averaged Brunt-Väisälä frequency $(\langle N\rangle)$ In $\mathrm{min}^{-1}$, for all boxes into which the Ría de Arousa was segmented depth-averaged Brunt-Väisälä frequency and the upward current. The enhancement of residual flows in the ría $\left(\left|V_{l}\right|>7.5 \mathrm{~m} \mathrm{~d}^{-1}\right)$ by intense upwelling $\left(I_{\mathrm{w}}>\right.$ $\left.1000 \mathrm{~m}^{3} \mathrm{~s}^{-1} \mathrm{~km}^{-1}\right)$ or downwelling $\left(I_{\mathrm{w}}<-1000 \mathrm{~m}^{3} \mathrm{~s}^{-1}\right.$ $\mathrm{km}^{-1}$ ) on the shelf is always accompanied by a marked decrease in water column stability $\left(<N><1 \mathrm{~min}^{-1}\right)$ However, with intermediate flows $\left(\left|v_{z}\right|<7.5 \mathrm{~m} \mathrm{~d}^{-1}\right)$, $<N>$ ranges from maximum values to values as low as those observed when estuarine circulation was enhanced. The reason for this broad variability in stability is the stratification of the water column before every upwelling event, i.e. its 'resistance' $(<N>)$ against a 'deforming' agent $\left(I_{v^{\prime}}\right)$. An intermediate upwelling pulse $\left(I_{w}<1000 \mathrm{~m}^{3} \mathrm{~s}^{-1} \mathrm{~km}^{-1}\right)$ can lift and compress a strong pycnocline by vertical advection, increasing $N$. In contrast, homogenization by turbulent diffusion occurs when previous water column stability is low, which then decreases $N$.

\section{Nitrogen speciation at the reference station}

Nitrate was the prevalent inorganic nitrogen species in the lower layer at Stn 4 (Fig 6a), with an average concentration of $5.7 \pm 2.2 \mu \mathrm{mol} \mathrm{kg}^{-1}$ Nitrate concentrations can exceed $9 \mu \mathrm{mol} \mathrm{kg}{ }^{-1}$ during the strongest upwelling events that force larger volumes of deeper ENAW over the shelf (Fraga 1981, Blanton et al. 1987), enhancing both water influx and nitrate concentrations in the ría. Some coupling between water displacements and nitrate levels in the lower layer can be observed in the time course of the 5 to $9 \mu \mathrm{mol} \mathrm{kg}{ }^{-1}$ nitrate isolines and the 26.7 to 26.9 isopycnals. In the upper layer, where the average concentration was 2.1 $\pm 2.1 \mu \mathrm{mol} \mathrm{kg}{ }^{-1}$, a cycle of net consumption by biological activity followed by replenishment via upwelling can explain the observed variability. Maximum nitrate concentration, $>7 \mu \mathrm{mol} \mathrm{kg}^{-1}$ at the sea surface, was measured during the strong upwelling event on September 4 (Survey 30). The nitrite profile (Fig 6b) showed a time course similar to that of nitrate in the upper and lower layers, providing evidence of a common origin and common sources of variability for the most axidised inorganic nitrogen forms. Nitrite played a secondary role in the nitrogen cycle, as it constituted only $-5 \%$ of DIN. The average concentrations in the upper and lower layers were $0.18 \pm 0.16$ and $0.41 \pm$ $0.11 \mu \mathrm{mol} \mathrm{kg}{ }^{-1}$ respectively. By contrast, ammonium followed a pattern opposite to that of nitrate and nitrite (Fig. 6c). It decreased below $1 \mu \mathrm{mol} \mathrm{kg}{ }^{-1}$ during strong upwelling events and increased over $2 \mu \mathrm{mol} \mathrm{kg}^{-1}$ when water circulation was slow becuuse of relaxed upwelling. It can clearly be observed on Surveys 10,25 and 37 , which coincided with remarkable water column stability maxima (Fig. 3c). 

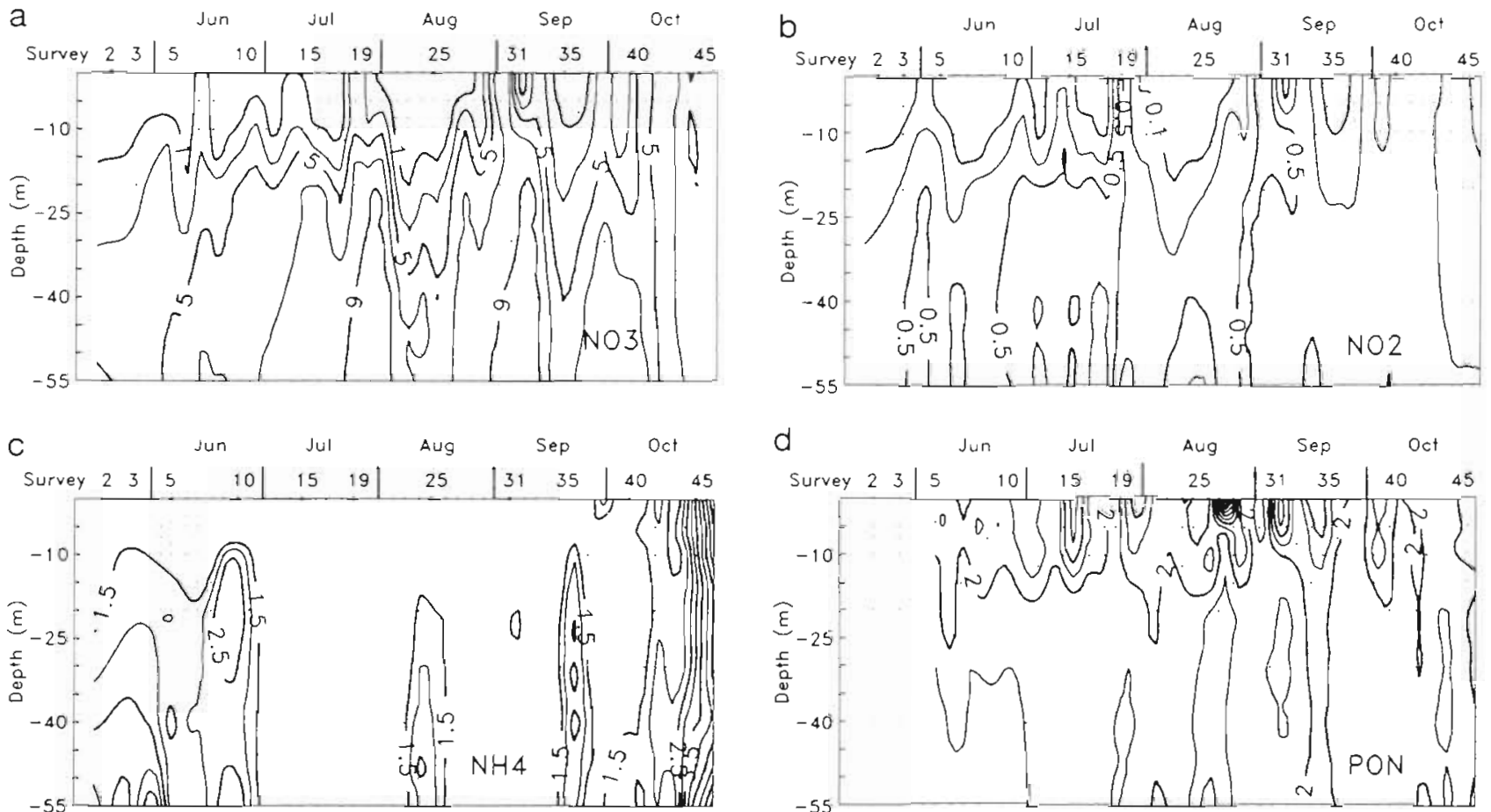

Fig. 6. Time course of (a) nitrate, (b) nitrite, (c) ammonium and (d) particulate organic nitrogen in $\mu \mathrm{mol} \mathrm{kg}^{-1}$ at Stn 4 . Interval between PON lines is $1 \mu \mathrm{mol} \mathrm{kg}{ }^{-1}$ PON increases from bottom to surface waters

In upwelling conditions, the inward flow consists of ammonium-free ENAW that has been aged on the shelf. Although ENAW is also nitrite-free (Fraga et al. 1987), relatively high levels $\left(>0.4 \mu \mathrm{mol} \mathrm{kg}^{-1}\right.$ ) of this form can be observed in the incoming water (Fig 6b). This fact supports the hypothesis that rapid nitrification processes occur over the shelf and in the ría up to the middle Stn 4, partially at the expense of POM being exported from the inner Ría rather than sinking (Alvarez-Salgado et al. 1993, Prego 1994). In contrast, when estuarine circulation is blocked, the bulk of the sinking POM inside the ría may settle on the bottom. Accordingly, high organic matter content has been measured in surface sediments of the Ría de Arousa (Tenore et al. 1982, López-Jamar et al. 1992), as has been observed in other estuarine and coastal areas where mussel culture is developed (Smaal \& Prins 1993). Benthic ammonification and subsequent sediment-water exchange seem to be the most likely mechanisms responsible for ammonium accumulation during upwelling relaxations, when residence time of water in the lower layer is $>5 \mathrm{~d}$ at Stn 4 (Rosón et al. in press) Amonium concentrations of 0.3 to $2.2 \mu \mathrm{mol} \mathrm{kg}{ }^{-1}$ would have been measured in the lower $20 \mathrm{~m}$ after $2 \mathrm{~d}$, provided that release of 125 to $900 \mu \mathrm{mol} \mathrm{m}^{-2} \mathrm{~h}^{-1}$ occurred, as was calculated for the Ría the Arousa by Tenore et al. (1982) from integrated sulphate reduction rates. This agrees with the characteristic high diffusion rates from sediments in areas of mussel harvesting
(Baudinet et al. 1990). In contrast, residence time dramatically decreases with upwelling to less than $1 \mathrm{~d}$, and the ammonium maxima are rapidly dispersed by the aged ENAW. Consequently, during upwelling events DIN consisted mainly of external nitrate, whereas internal ammonium became important during relaxations.

During the autumn downwelling event, maximum ammonium concentrations were measured $(>4 \mu \mathrm{mol}$ $\mathrm{kg}^{-1}$ ), while nitrate diminished below $1 \mu \mathrm{mol} \mathrm{kg}{ }^{-1}$, both forms being homogeneously distributed by strong vertical mixing in the whole water column. This ammonium distribution is inconsistent with the circulation pattern, because the nutrient-free shelf surface waters were then flowing rapidly into the ría. High ammonium levels have already been reported in the Spanish rías (Cabanas et al. 1983, Rios 1992, Figueiras et al. 1994) at this time of year, and coincide with the characteristic autumn maximum observed in temperate ecosystems (Spencer 1975). Consequently, the ammonium maximum resulted from biogeochemical processes independent of water circulation, in contrast to the coupling observed during the previous succession of upwelling/ relaxation events. In the innermost part of the estuary, this is thought to be related to the degradation of the large population of macrophytes (Pérez et al. 1992).

The distribution of PON concentrations over time at Stn 4. (Fig. 6d) was complementary to that of nitrogen salts, with an average concentration of $2.60 \pm 0.49$

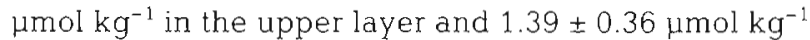


in the lower layer. Nitrate depletion in surface waters led to PON increase because of the exchange between both nitrogen pools by net phytoplankton growth. Obviously, losses by sedimentation and conversion to DON reduced the efficiency of this exchange, which is evaluated below in the examination of biogeochemical budgets. On the contrary, during strong upwelling events, 'wash-out' of the accumulated PON took place. The high correlation between the average PON and $c h$ l $a$ in the uper and lower layers $\left(r^{2}=0.81\right)$ supports this statement:

$[\mathrm{PON}]=1.0( \pm 0.4)+0.45( \pm 0.02)[\mathrm{chl} a]$

Average chl a concentration was $3.45 \pm$ $2.27 \mathrm{Hg} \mathrm{l}^{-1}$ and $1.01 \pm 0.83 \mathrm{\mu g} \mathrm{l}^{-1}$ in the upper and lower layers respectively. This means that about $39 \%$ of total PON in the upper layer consisted of heterotrophs and/or detritus. In the lower layer, these comprised $69 \%$ of total PON, as calculated from the relative contribution of the origin intercept term and the slope $\times$ average [chl a] term in Eq. (11)

\section{Net DIN fluxes and budgets}

Fig. 7 a summarises the average net DIN fluxes supplied to both layers of Box 4 (Fig. 1) by convective-diffusive circulation during the upwelling season, i.e. from June 8 up to October 13, when the autumn downwelling event started.

Runoff (not shown) represented only $0.3 \%$ of the DIN supplied to the upper layer of Box 4 , and is not considered in our calculations. For the whole ria, the continental input constituted about $3 \%$ of the total DIN input. It became important in the innermost part, where $20 \%$ of the DIN (70\% as nitrate, and $30 \%$ as ammonium on average) which entered Box 1 (Fig. 1) was transported by the River Ulla (Pérez et al. 1992). Consequently, the available external DIN in Box 4 came from the shelf $\left(17.9 \mathrm{~mol} \mathrm{~s}^{-1}\right.$ on average, and 2 - to 3 -fold higher during the strongest upwelling events). However, the low efficiency of the inner part of the ria $(4.5 / 9.2=0.5)$ in retaining the DIN input favoured a significant DIN input from the upper layer of the inner boxes, driven by the 2-layer residual circulation pattern. In this upper horizontal flow (water which had undergone more intense biôgeochemical trañuformat tions as it passed through the inner ria) the percentage of ammonium was almost twice as high as in the lower incoming flow. a Upwelling season
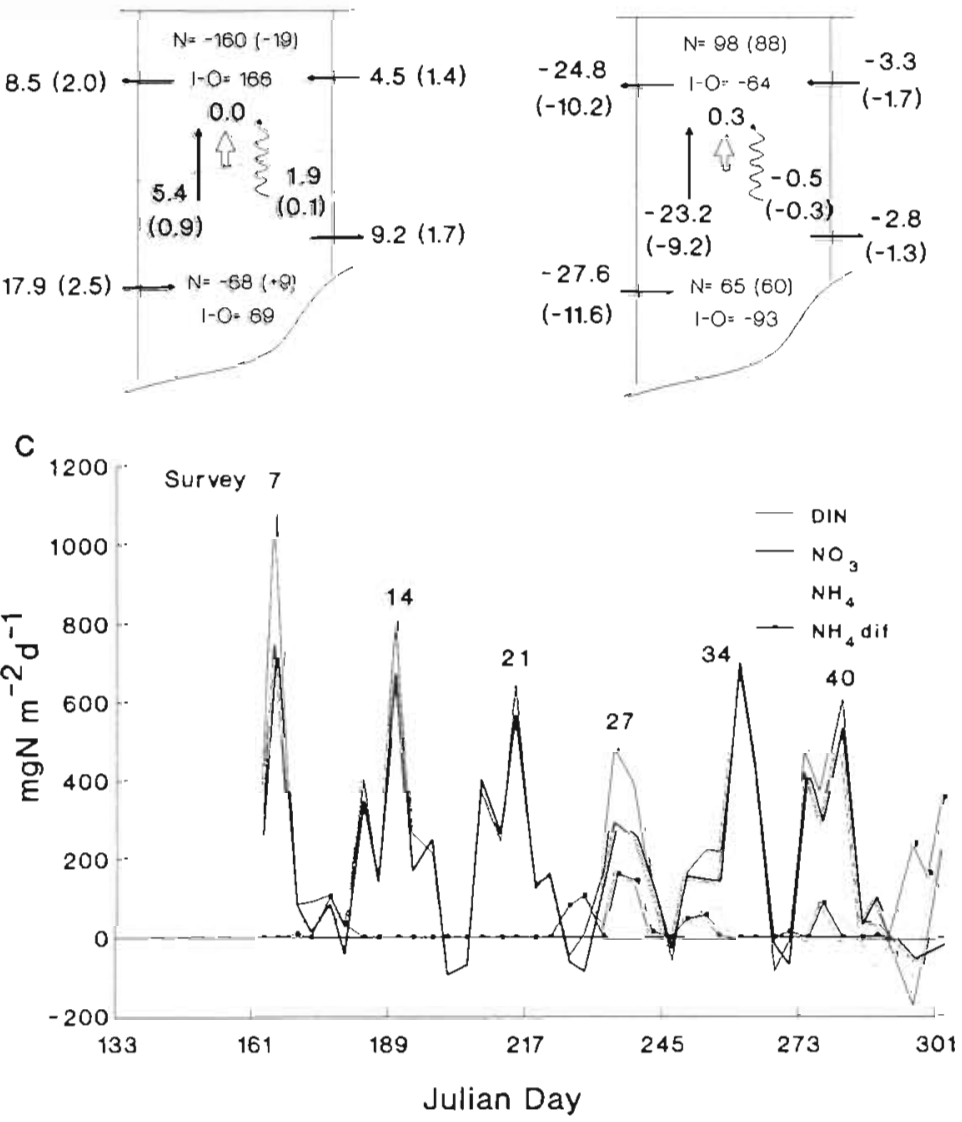

Fig. 7 Fluxes ( $\mathrm{mol} \mathrm{N} \mathrm{s} \mathrm{s}^{-1}$ ) and net budgets $\left(\mathrm{mg} \mathrm{N} \mathrm{m} \mathrm{N}^{-2} \mathrm{~d}^{-1}\right.$ ) of dissolved inorganic nitrogen (DIN) in Box 4: (a) averaged over the upwelling season (June 8 to October 13) and (b) averaged over the autumn downwelling event (October 13 to 31 ). Values in parentheses indicate ammonium fluxes or net budgets (bold values correspond to fluxes). See Fig. 2 for explanation of arrows. $\mathrm{I}-\mathrm{O}$ is the net budget of inputs minus outputs, $N(=-N C P)$ represents production of DIN by biogeochemical processes. I-O plus $N$ corresponds to the hydrodynamic accumulation term. (c) Time course of net uptake of DIN (pelagic NCP), nitrate $\left(\mathrm{NO}_{3}\right)$, ammonium $\left(\mathrm{NH}_{4}\right)$ and ammonium diffused from the sediments $\left(\mathrm{NH}_{4}\right.$ dif) for Box 4 dunng the study period $\left(\mathrm{mg} \mathrm{N} \mathrm{m}^{-2} \mathrm{~d}^{-1}\right)$
Box 4 retained $21 \%\left(235 \mathrm{mg} \mathrm{m}^{-2} \mathrm{~d}^{-1}\right)$ of the external DIN input. When integrated over the upwelling season, DIN was almost completely trapped by biogeochemical processes $(97 \%)$, making the hydrodynamic

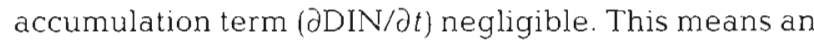
average $\mathrm{NCP}$ of $228 \mathrm{mg} \mathrm{N} \mathrm{m} \mathrm{m}^{-2} \mathrm{~d}^{-1}$ (or $1174 \mathrm{mg} \mathrm{C} \mathrm{m} \mathrm{m}^{-2}$ $\mathrm{d}^{-1}$ if a $\mathrm{C} / \mathrm{N}$ molar ratio of 6 is assumed). This value constitutes a realistic estimation of NCP for the upwelling season as it results from an average over the fortnightly succession of upwelling/relaxation events that took place during this period. Prego (1993a)

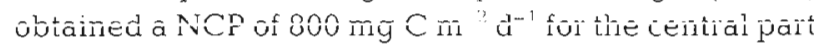
of the adjacent Ría de Vigo during a vigorous upwelling event. Nitrate was the most efficiently trapped nitrogen salt, supporting $89 \%$ of NCP in the central 
segment of the Ria de Arousa. This agrees with calculations of NCP in. upwelling areas from estimations of net nitrate consumption (Minas et al. 1986). On the other hand, the average recycling time of ammonium seemed to be close to the mean residence time of water inside the box ( $-2 \mathrm{~d})$ as only $5 \%$ of the total input of ammonium was retained. This could explain the larger percentage of ammonium in the upper flows. The upper layer retained $28 \%$ of the DIN input, accounting for $70 \%$ of the total NCP. The main source of DIN was the lower layer $(46 \%$ by advection and $16 \%$ by turbulent diffusion). Entrainment is negligible for this longterm $(154 \mathrm{~d})$ average, as it is only significant when changes in volume of layers over short time intervals are considered. The net budget for the lower layer indicated that $8 \%$ of the total DIN input was retained by net consumption of nitrate $(30 \%$ of total NCP in the box). This is consistent with the relatively high average chl a values. Ammonium was regenerated at an average net rate of $9 \mathrm{mg} \mathrm{m}^{-2} \mathrm{~d}^{-1}$.

The time course of NCP in Box 4 for the upwelling season is shown in Fig. $7 \mathrm{C}$. In the present calculation the net contribution of the sediments was considered when $E_{N}$ in Eq. (6) was negative. This approach distinguishes between net pelagic and net benthic ammonification (with release to the water column) when regeneration prevails. On the other hand, for those periods when the removal of DIN carried by flowing water did not compensate for pelagic organic nitrogen (dissolved plus particulate) production, a net ammonium flux from the sediments was assumed in order to balance the system. In these cases, an equal amount of PON may settle over the bottom of the box. This is called pelagic NCP, as opposed to the total NCP presented earlier. Average pelagic NCP was $251 \mathrm{mg} \mathrm{N}$ $\mathrm{m}^{-2} \mathrm{~d}^{-1}$ for the upwelling season, $23 \mathrm{mg} \mathrm{m}^{-2} \mathrm{~d}^{-1}(10 \%)$ more than total NCP This excess was associated with net ammonium release from the sediments.

Six NCP maxima can be distinguished: on June 15 (Survey 7), July 10 (Survey 14), August 3 (Survey 21) and 24 (Survey 27), September 18 (Survey 34) and October 9 (Survey 40). These maxima were all related to wind-driven upwelling events that forced DIN from. the shelf into the ria. The short-time-scale coupling between input and net uptake of nutrient salts is investigated in the companion paper (Alvarez-Salgado et al. 1996) These maxima were interrupted by short intervals of low production or even net regeneration in the water column, which occurred when the system was not under wind-forced conditions. Although pelagic NCP occurred through net uptake of allochthonous nitrate, $26 \%$ of NCP was sustained by ammonium diffusing from the sediments for the peak centered on August 24, when moderate upwelling compressed the pycnocline, producing a stability maximum. This co- incided with the final stage of a short-time-scale phytoplankton succession in which the fish-killers Gyrodinium sp. and Heterosigma akashiwo were the prevailing microplankton species (Pazos et al. 1995).

During the autumn downwelling event (Fig 7b) the situation was quite different. Because of the persistent reversal in estuarine circulation, $24.8 \mathrm{~mol} \mathrm{~s}^{-1}$ of DIN entered the upper layer from shelf surface waters. Much of this DIN was transferred to the lower layer by vertical convection and returned again to the shelf. Ammonium represented more than $40 \%$ of the DIN in any flux. Net DIN regeneration occurred in both layers, at a total average rate of $163 \mathrm{mg} \mathrm{m}^{-2} \mathrm{~d}^{-1}, 92 \%$ as ammonium. The sediments released $162 \mathrm{mg} \mathrm{m}^{-2} \mathrm{~d}^{-1}$ or $480 \mu \mathrm{mol} \mathrm{m}^{-2} \mathrm{~h}^{-1}$, which is similar to the highest values reported in the literature (Baudinet et al. 1990, Lerat et al. 1990). Hydrodynamic accumulation of regenerated ammonium took place in the upper layer at a net rate of $34 \mathrm{mg} \mathrm{m}^{-2} \mathrm{~d}^{-1}$, while an equivalent net loss was obtained in the lower layer. A net DIN transport of $15 \mathrm{mg} \mathrm{m}^{-2} \mathrm{~d}^{-1}$ occurred from the lower to the upper layer by entrainment of layers.

\section{Biogeochemical cycle of nitrogen species}

The net balance of biogeochemical processes during the upwelling season contributes mainly to increasing the DON pool (Fig. 8a, c). As much as $146 \mathrm{mg} \mathrm{m}^{-2} \mathrm{~d}^{-1}$ on average was produced in Box 4, which represents $58^{\circ} \div$ of pelagic NCP This is probably the result of the low trophic web efficiency of hanging mussels and agrees with the proposal of Jumars et al. (1989) on the biological origin of DOM. About $60 \%\left(\sim 10 \mu \mathrm{mol} \mathrm{kg}^{-1}\right)$ of the total organic nitrogen (TON) determined by Fraga (1960) in the adjacent Ría de Vigo was DON (1 yr average). This author also found a nearly constant amount of refractory DON, $\sim 7 \mu \mathrm{mol} \mathrm{kg}^{-1}$, which was not directly involved in the biogeochemical cycle of nitrogen. In Marlborough Sounds (New Zealand), where mussels are also intensively cultured, more than $80 \%$ of TON exists in dissolved form (Kaspar et al 1985). The remainder of pelagic NCP, $106 \mathrm{mg} \mathrm{m}^{-2} \mathrm{~d}^{-1}$. contributed to the total PON pool, though half of that settled over the sediment-water interface, which is in agreement with the high sedimentation rates found in ecosystems affected by mussel harvesting (Kaspar et al. 1985, Kautsky \& Evans 1987, Rodhouse \& Roden 1987). This PON came from the upper layer, where $97 \%$ of the net PON production occurred. In the lower layer, the large increase observed in the DON pool almost equalled the net uptake of DIN.

However, for the maximum on August 24 (Fig. 8c), DIN uptake led mainly to an increase in the pelagic PON pool. Therefore, it seems that hanging mussel fil- 
a

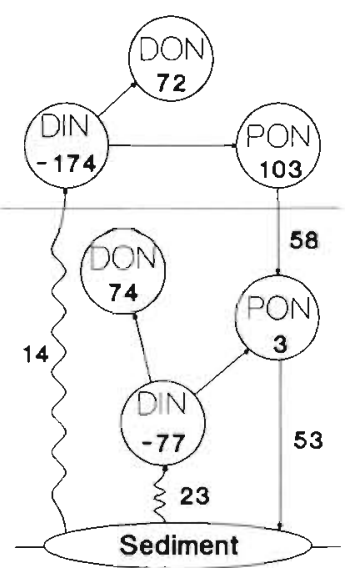

b Autumn Downwelling

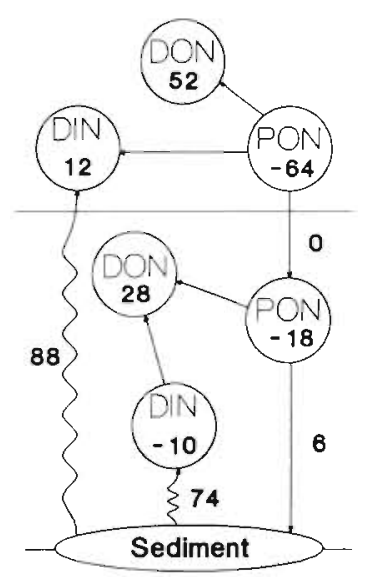

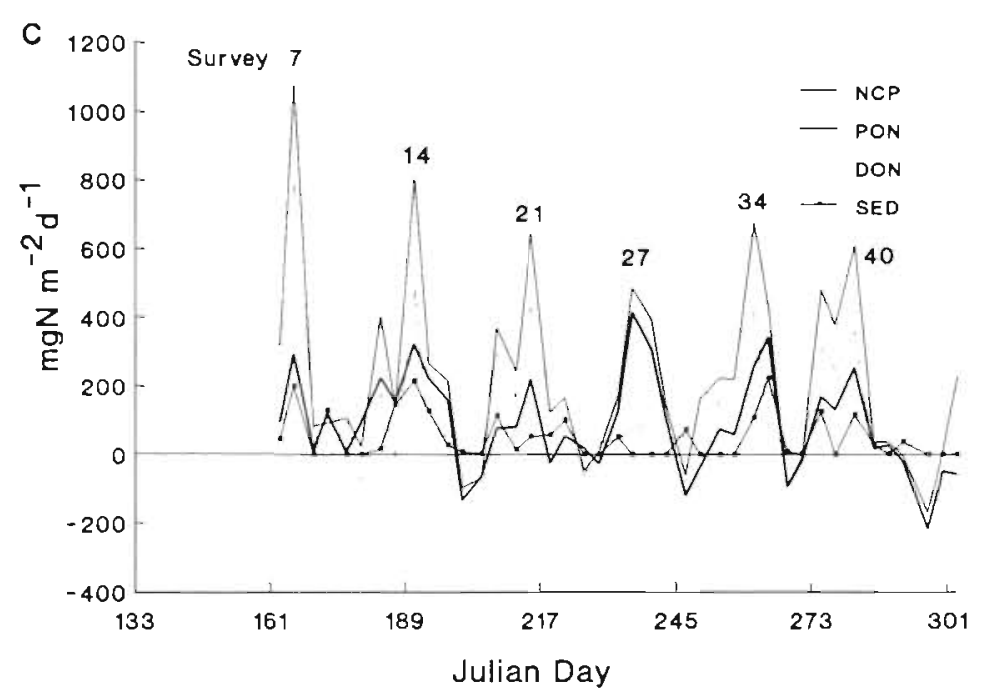

Fig. 8. Net biogeochemical budget for each nutrogen pool ( $\mathrm{mg} \mathrm{N} \mathrm{m}^{-2} \mathrm{~d}^{-1}$ ) in Box 4 averaged for the upper and lower layers: (a) dunng the upwelling season, June 8 to October 13; (b) during the autumn downwelling event, October 13 to 31 , 1989j. (c) Time course of each pool for the whole box during the study period. Curved arrows represents net release of ammonium from the sediments. NCP: community production; PON: particulate organic nitrogen; DON: dissolved organic nıtrogen; SED: net sedimentation

\section{Gross primary production versus net community production}

In Fig 9, GPP at Stn 4, roughly estimated by Eq (10), is compared with NCP in Box 4 for the period when ${ }^{14} \mathrm{C}$ incubations were performed. In spite of the fact that GPP can only be used for semiquantitative purposes (see 'Material and methods'), that GPP and NCP refer to different volumes (a single station and a box, respectively), and that a constant $\mathrm{C} / \mathrm{N}$ molar ratio of 6 has been assumed, the comparison of both calculated variables reveals valuable, and not previously reported, information about the new and recycled production in the Ría de Arousa. These methodological problems lead, in a few cases, to NCP values that are slightly higher than GPP values, which is theoretically impossible. tration rate dramatically diminished when this red tide assemblage prevailed. Reduced predation on red tide organisms by other herbivores such as zooplankton has been proposed to occur (Fielder 1982, Ives 1987). Although low growth rates of mussels fed with dinoflagellates have been observed in batch cultures (Bricelj et al. 1993), this is likely the first evidence of such behaviour in the field. The low phaeopigment concentration in the water column (Pazos et al. 1995) supports this statement. Net PON settlement did not occur, corresponding with low production of large faecal pellets by mussels and the ability of red tide organisms to avoid sinking, in contrast to diatoms (Smayda \& Bienfang 1983, Cushing 1989).

For the autumn downwelling event (Fig. 8b, c) net regeneration of PON increased the DON pool at an arerage rate of $80 \mathrm{mg} \mathrm{m}^{-2} \mathrm{~d}^{-1}$, while ammonium diffused from the sediment in both the upper $\left(88 \mathrm{mg} \mathrm{m}^{-2}\right.$ $\mathrm{d}^{-1}$ ) and lower ( $74 \mathrm{mg} \mathrm{m}^{-2} \mathrm{~d}^{-1}$ ) layers accounts for the increase in the DIN pool mentioned above.

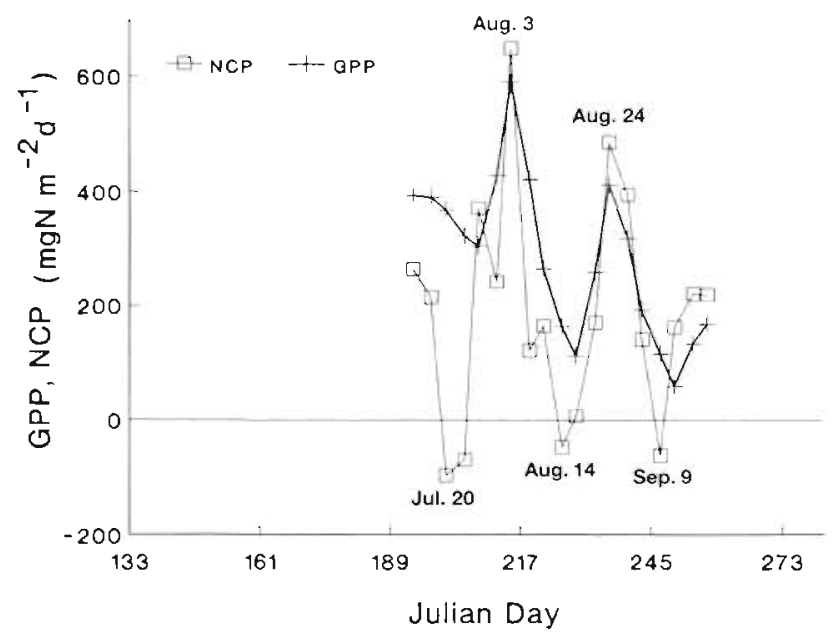

Fig. 9. Comparative time evolution of integrated gross primary production (GPP) and net community production (NCP) for Box 4 from. July 10 to Sentemher 14, 1989 GPP in nitrongen units was obtained by multiplying GPP $\left(\mathrm{mg} \mathrm{C} \mathrm{m}^{-2} \mathrm{~d}^{-1}\right)$ by an average $\mathrm{N} / \mathrm{C}$ molar ratio of $1 / 6$, then by the atomic weight of nitrogen divided by the atomic weight of carbon [(GPP/6) $(14 / 12)]$ 
NCP clearly converged towards GPP for the event centered on August $3\left(590 \mathrm{mg} \mathrm{N} \mathrm{m}{ }^{-2} \mathrm{~d}^{-1}\right)$. This indicates that in upwelling conditions, internally recycled DIN (mainly ammonium) did not play an important role in the primary production of the ecosystem. The same occurred for the conspicuous primary production peak of $410 \mathrm{mg} \mathrm{m}^{-2} \mathrm{~d}^{-1}$ on August 24, although, as indicated before, $26 \%$ of the NCP was supported by ammonium diffused from the sediments, i.e. by regenerated organic nitrogen previously trapped inside the box. GPP and NCP diverged most during upwelling relaxations, when water column stability increased and the external input of nutrients was rather limited. This was the situation for the periods centered on July 20, August 14 and September 9, when regeneration (GPP minus NCP) of 370,115 and $60 \mathrm{mg} \mathrm{m}^{-2} \mathrm{~d}^{-3}$, respectively, took place. For those dates, primary production was exclusively supported by internally recycled nitrogen (NCP was even negative).

Mean daily GPP for the period of $P-I$ incubations (66 d) was $1470 \mathrm{mg} \mathrm{C} \mathrm{m}^{-2} \mathrm{~d}^{-1}$ (about $285 \mathrm{mg} \mathrm{N} \mathrm{m}^{-2} \mathrm{~d}^{-1}$ ). For the same period, NCP was $180 \mathrm{mg} \mathrm{N} \mathrm{m}^{-2} \mathrm{~d}^{-1}$. This means that $37 \%$ of the phytoplankton primary production was respired by the community of organisms inside Box 4. This must be associated with a rapid recycling of organic nitrogen to ammonium, in contrast with the NCP (at the expense of external nitrate) which can be equated to the new or exported production of the pelagic ecosystem (Eppley 1989, Quiñones \& Platt 1991). The average $f$-ratio of Eppley \& Perterson (1979) was about 0.4, close to values obtained in highly productive ecosystems (Eppley 1989, Chisholm 1992, Dugdale \& Wilkerson 1992). However, external cannot be considered synonymous with allochthonous, since a significant part of the incoming nitrate flux during upwelling events has been regenerated over the shelf by rapid oxidation of sinking POM partially outwelled from the rias (Alvarez-Salgado et al. 1993, Prego 1994). This would reduce the expected $f$-ratio when the riashelf system is considered as a whole. This common mechanism of nutrient-salt trapping by the circulation pattern in upwelling areas (Barber \& Smith 1981 . Codispoti 1983) is favoured by the presence of large coastal inlets such as the rías, in which residence time of upwelled water is increased considerably. The total volume of the 4 Rias Baixas, $1.36 \times 10^{10} \mathrm{~m}^{3}$ (Fraga \& Margalef 1979), represents about $4 \%$ of the adjacent shelf.

\section{SUMMARY AND CONCLUSIONS}

The distribution of nitrogen species in the central part of the Ría de Arousa is the consequence of a hydrodynamic regime dominated by the influence of wind-driven upwelling on estuary-like water circulation and a biogeochemical cycle affected by the most intensive hanging mussel harvesting in the world.

Upwelling determines nutrient fluxes into the ría. Northerly winds over the shelf followed a 2 wk stressrelaxation cycle, and nitrate-rich ENAW entered the estuary with this periodicity, determining the succession of NCP maxima which were then supported mainly by external nitrate. However, part of the nitrate came from over-shelf recycling of organic matter partially exported from the ria. Although the segment studied only retains $1 / 5$ of the total nutrient input, due to the rapid water circulation, resulting NCP was high: $251 \mathrm{mg} \mathrm{m}^{-2} \mathrm{~d}^{-1}$ on average over the upwelling season. Most of this NCP led to an increase in the net or export DON pool (58\%), while $21 \%$ contributed to the suspended PON and the remaining $21 \%$ settled to the sediment-water interface. Therefore, more than $3 / 4$ of the net organic matter produced can be exported out of the box, with a DON/PON ratio of $\sim 3$. In addition, if the obtained NCP/GPP ratio (0.6) is extrapolated for the whole upwelling season, $40 \%$ of the phytoplankton gross primary production $(f$-ratio $=0.4)$ would be recycled by pelagic + benthic ammonification inside the box. Recycling occurred mainly when the system was under non-wind-forced conditions (high water stratification) and when low external nutrient supply took place. The settled-PON pool includes organic matter removed by mussel cultivation, which was roughly estimated as $5 \mathrm{mg} \mathrm{m}^{-2} \mathrm{~d}^{-1}$ (see 'Introduction'), i.e. $\sim 10 \%$ of the pool, or $\sim 2 \%$ of the pelagic NCP or $\sim 1 \%$ of the GPP. Consequently, although mussel harvesting does not represent a significant nitrogen loss for the system, it clearly conditions the redistribution of nitrogen pools by 'catalysing' DON formation and PON sedimentation. By contrast, during a NCP maximum dominated by a red tide assemblage, DIN uptake led to an increase in the suspended-PON pool, when conversion to DON and sedimentation were largely prevented. This constitutes field evidence of low filtration rates of harvested mussels in the presence of red tide organisms.

During the characteristic transition from northerly to southerly winds in mid-October, a strong downwelling event over the shelf forced a reversal in the water circulation, with nutrient-depleted shelf surface waters entering the ria. However, ammonium concentration in the water column largely increased because of an average net release of $480 \mu \mathrm{mol} \mathrm{NH}_{4}{ }^{+} \mathrm{m}^{-2} \mathrm{~h}^{-1}$ from the sediment-water interface.

Acknowledgements. The authors thank all the participants in the GALICIA-X cruise, especially T Rellán and R. Penín, for their unconditional devotion. We are also very grateful to the crew of the RV 'Investigador S.', who were always ready to help us. Support for this work came from C.I.C.Y.T Grant No. 
MAR88-0245 and funds from the Conselleria de Pesca da Xunta de Galicia. Fellowships from the Spanish Ministerio de Educación y Cienca allowed X.A.A.-S., G.R. and Y.P. to carry out their Ph.D. theses as part of this project. We also thank Dr E. Fernández for his valuable comments and criticisms and Dr A. Miller for correction of the English. Prof. K. Tenore, Prof. R. G. Wiegert and 3 anonymous reviewers provided valuable criticisms of the manuscript.

\section{LITERATURE CITED}

Alvarez-Salgado XA, Pérez FF, Fraga F (1992) Determination of nutrient salts by automatic methods both in seawater and brackish water: the phosphate blank. Mar Chem 39: $311-319$

Alvarez-Salgado XA, Rosón G, Pérez FF, Figueiras FG, Ríos AF (1996) Nitrogen cycling in an estuarine upwelling system, the Ría de Arousa (NW Spain). II. Spatial differences in the short-time-scale evolution of fluxes and net budgets. Mar Ecol Prog Ser 135:275-288

Alvarez-Salgado XA, Rosón G, Pérez FF, Pazos Y (1993) Hydrographic variability off the Rías Baixas (NW Spain) during the upwelling season. J Geophys Res 98(C8): $14447-14455$

Baker KS, Frouin R (1987) Relation between photosynthetically available radiation and total isolation at the ocean surface under cloudy skies. Limnol Oceanogr 32: $1370-1377$

Barber RT, Smith RL (1981) Coastal upwelling ecosystems. In: Longhurst AR (ed) Analysis of marine systems. Academic Press, San Diego, p 31-68

Baudinet D, Alliot E, Berland B, Grenz C, Plante-Cuny MR, Salen-Picard C (1990) Incidence of mussel culture on biochemical fluxes at the sediment-water interface. Hydrobiologia 207:187-196

Blanton JO, Atkinson LP, Castillejo FF, Lavín A (1984) Coastal upwelling off the Rías Bajas, Galicia, Northwest Spain, I: Hydrographic studies. Rapp P-V Réun Cons Int Explor Mer 183:79-90

Blanton JO, Tenore KR, Castillejo FF, Atkinson LP, Schwing FB, Lavín A. (1987) The relationship of upwelling to mussel production in the rías on the western coast of Spain. J Mar Res 45:497-511

Boynton WR, Kemp WMI, Keefe CW (1982) A comparative analysis of nutrients and other factors influencing estuarine phytoplankton productions. In: Kennedy VS (ed) Estuarine compansons. Academic Press, New York, p $69-90$

Bricelj VM, Greene M, Cembella AD (1993) Growth of the blue mussel Mytilus edulis on toxic Alexandrium fundyense and effects of gut passage on dinoflagellate cells. In: Smayda TJ, Shimizu Y (eds) Toxic phytoplankton blooms in the sea. Elsevier, Amsterdam, p 371-376

Cabanas JM, González JJ, García-Fernández C (1983) Nutrientes en la Ría de Arousa: distribución e interrelación. Bol Inst Esp Oceanogr 1:72-84

Cabanas JM, González JJ, Mariño J, Pérez A, Román G (1979) Estudio del mejillon y su epifauna in los cultivos flotantes de la Ría de Arousa III: observaciones previas sobre la retención de particulas y la biodepositión de una batea. Bol Inst Esp Oceanogr 5:45-50

Carpenter EJ, Capone DG (eds) (1983) Nitrogen in the marine environment. Academıc Press, New York

Carte HH, Najarian TO, Pritchard DW, Wilson RE (1979) The dynamics of motion in estuaries and other coastal water bodies. Rev Geophys Space Phys 17:1585-1590
Chisholm SW (1992) Phytoplankton size. In: Falkowsky PG, Woodhead AD (eds) Primary productivity and biogeochemical cycles in the sea. Plenum, New York, p 213-238

Codispoti LA (1983) Nitrogen in upwelling systems. In: Carpenter EJ, Capone DG (eds) Nitrogen in the marine environment. Academic Press, New York, p 513-564

Cushing DH (1989) A difference in structure between ecosystems in strongly stratified waters and those that are only weakly stratified. J Plankton Res 11:1-13

Dietrich G, Kalle K, Krauss W, Siedler G (1980) General oceanography: an introduction, 2nd edn. J Wiley \& Sons, New York

Dugdale R, Wilkerson F (1992) Nutrient limitation of new production in the sea. In: Falkowsky PG. Woodhead AD (eds) Primary productivity and biogeochemical cycles in the sea. Plenum, New York, p 107-122

Eppley RW (1989) New production: history, methods, problems. In: Berger WH, Smetacek VS, Wefer G (eds) Productivity of the ocean, present and past. Wiley \& Sons, Chichester, p 85-97

Eppley RW, Peterson BJ (1979) Particulate organic matter flux and planktonic new production in the deep ocean. Nature $282 ; 677-680$

Fielder PC (1982) Zooplankton avoidance and reduced grazing response to Gymnodinium splendens (Dynophyceae) Limnol Oceanogr 27:961-965

Figueiras FG, Jones KJ, Mosquera AM, Alvarez-Salgado XA McDougall N (1994) Red tide assemblage formation in a estuarine upwelling ecosystem: Ria de Vigo. J Plankton Res 16:857-878

Figueiras FG, Pazos Y (1991) Microplankton assemblages in three Rías Balxas (Vigo, Arosa and Muros, Spain) with a subsurface chlorophyll maximum: their relationships to hydrography. Mar Ecol Prog Ser 76:19-233

Fraga F (1960) Variación estacional de la materia orgánica suspendida y disuelta en la Ría de Vigo. Influencia de la luz y la temperura. Invest Pesq 17:127-140

Fraga F (1967) Hidrografía de la Ría de Vigo 1962, con especial referencia a los compuestos de nitrógeno. Invest Pesq 31:145-259

Fraga F (1976) Fotosíntesis en la Ría de Vigo. Invest Pesq 40 $151-167$

Fraga F (1981) Upwelling off the Galician coast, northwest Spain. In: Richards FA (ed) Coastal upwelling. American Geophysical Union, Washington, DC, p 176-182

Fraga F, Figueiras FG, Prego R, Pérez FF, Ríos AF (1987) Campaña 'Galicia IX' oceánica. Datos Inf Inst Inv Mar 20

Fraga F, Margalef R (1979) Las Rías Gallegas. In: Estudio y explotación del mar en Galicia. Universidad de Santiago de Compostela, Santiago de Compostela, p 101-121

Garber JH (1984) Laboratory study of nitrogen and phosphorus remineralization during the descomposition of coastal plankton and seston. Estuar Coast Shelf Sci 18:685-702

Hansen HP, Grasshoff K (1983) Automated chemical analysis. In: Grasshoff K, Ehrhardt M, Kermling K (eds) Methods of seawater analysis, 2nd edn. Verlag Chemie, Weinheim, p 347-395

Hanson RB, Alvarez-Ossorio MT, Cal R, Campos MJ, Román M, Santiago G, Varela M, Yoder JA (1986) Plankton response following a spring upwelling event in the Ría de Arosa, Spain. Mar Ecol Prog Ser 32:101-113

Hedges JI, Lee C (eds) (1993) Measurements of dissolved organic carbon and nitrogen in natural waters. Proc NSF/NOAA/DOE Workshop, Seattle, WA, USA, 15-19 July 1991. Mar Chem 41(1-3)

Hidy GM (1972) A view of recent air-sea interaction research. Bull Am Meteorol Soc 53:1083-1102 
Howarth RW (1988) Nutnent limatation of net primary production in marine ecosystems. A Rev Ecol Syst 19:89-100

Ives JD (1987) Possible mechanism underlying copepod grazing to levels of toxucaty in red tide dinoflagellate. $J$ Exp Mar Biol Ecol 112:131-145

Jumars PA, Penry DL, Baross JA, Perry MJ, Frost BW (1989) Closing the microbial loop: dissolved organic carbon pathway to heterotrophic bacteria from incomplete ingestion, digestion and adsorption in animals. Deep Sea Res 36: 483-495

Kaspar HF, Gillispie PA, Boyer IC, Mackenzie AL (1985) Effect of mussel aquaculture on the nitrogen cycle and benthic communities in Kenepuru Sound, Marlborough Sounds, New Zealand. Mar Biol 85:127-136

Kautsky N, Evans S (1987) Role of biodeposition by Mytilus edulis in the circulation of matter and nutrients in a Baltic coastal ecosystem. Mar Ecol Prog Ser 38:201-212

Lerat Y, Lasserre P, le Corre P (1990) Seasonal changes in pore water concentrations of nutrients and their diffusive flux at the sediment-water interface. J Exp Mar Biol Ecol $135: 135-160$

López-Jamar E, Cal RM, González G, Hanson RB, Rey J, Santiago $G$, Tenore KR (1992) Upwelling and outwelling effects of the benthic regime of the continental shelf off Galicia, NW Spain. J Mar Res 50:465-488

Mantoura RFC, Martin JM, Wollast R (eds) (1991) Ocean margin processes in global change. Wiley \& Sons, Chichester

Matsukawa Y, Suzuki T (1985) Box model analysis of hydrography and behavior of nitrogen and phosphorus in an eutrophic estuary. J Oceanogr Soc Jap 41:407-426

Minas HJ, Minas M, Packard TT (1986) Productivity in upwelling areas deduced from hydrographic and chemıcal fields. Limnol Oceanogr 31:1182-1206

Miyata K, Hattori A (1986) A simple fractionation method for determination of phosphorus components in phytoplankton: application to natural populations of phytoplankton in summer surface waters of Tokio Bay. $J$ Oceanogr Soc Jap 42:255-265

Mouriño C, Fraga F (1.985) Determinación de nitratos en agua de mar. Invest Pesg 49:89-96

Navarro E, Iglesıas JIP, Pérez Camacho A, Labarta U, Beiras R (1991) The physiological energetics of mussels (Mytilus galloprovincialis $\mathrm{lmk}$ ) from different cultivation rafts in the Ría de Arosa (Galicia, NW Spain). Aquaculture 94:197-212

Niell FX, Mouriño C (1981) Contenido en carbono y nitrógeno en macrófitos intermareales. Invest Pesq 45:187-210

Officer CB (1980) Box models revisited. In: Hamilton P, MCDonald KB (eds) Estuarine and wetlands processes with emphasis on modeling. Plenum Press, NY, p 65-114

Otto L (1.975) Oceanography of the Ría de Arousa (NW Spain). Konink Meteor Int Med Verlan 96

Pazos Y, Figueiras FG, Alvarez-Salgado XA, Roson G (1995) The control of succession in red tide species in the Ría de Arousa (NW Spain) by upwelling and stability. In: Lassus P. Arzul G, Erad E, Gentien P. Marcaillou C (eds) Harmful algal blooms. Lavoisier, Intercept Ltd, Paris, p 645-650

Pérez FF, Alvarez-Salgado XA, Rosón G, Ríos AF (1992) Carbonic-calcium system, nutrients and total organic nitrogen in continental runoff to the Galician Rias Baixas, NW Spain. Oceanol Acta 15:595-602

Pérez-Camacho A, González R (1984) La filtración del mejillón (Mytilus edulis L.) en laboratorio. In: Actas do primeiro seminario de ciencias do mar. As rías galegas. Cuadernos da Area de Ciencias Marnnas. Seminario de Estudos Galegos $1: 427-437$

Platt T. (ed) (1981) Physiological bases of phytoplankton ecology. Can Bull Fish Aquat Sci 210
Platt T and 6 co-authors (1989) Brological production of the oceans: the case for a consensus. Mar Ecol Prog Ser 52: $77-88$

Platt T, Sathyendranath S, Ravindran P (1990) Primary production by phytoplankton: analytic solutions for daily rates per unit area of water surface. Proc R Soc Lond 241: $101-111$

Prego R (1993a) General aspects of carbon biogeochemistry in the Ría de Vigo, northwestern Spain. Geochim Cosmochim Acta 57:2041-2052

Prego R (1993b) Biogeochemical pathways of phosphorus in a Galician ría. Estuar Coast Shelf Sci 37:437-451

Prego R (1994) Nitrogen interchanges generated by biogeochemical processes in a Galician ría. Mar Chem 45: $167-176$

Prego R, Fraga F (1992) A simple model to calculate the residual flows in a Spanish ría. Hydrographic consequences in the Ría of Vigo. Estuar Coast Shelf Sci 34:603-615

Quinones RA, Platt T (1991) The relationship between the $f$ ratio and the P:R ratio in the pelagic ecosystem. Limnol Oceanogr 36:211-213

Ridal JJ, Moore RM (1990) A re-examination of the measurement of dissolved organic phosphorus in seawater. Mar Chem 29:19-31

Rios AF (1992) El fitoplancton de la Ría de Vigo y sus condiciones ambientales. PhD thesis, University of Santiago de Compostela

Rodhouse PJ, Roden CM (1987) Carbon budget for a coastal inlet in relation to intensive cultivation of suspensionfeeding bivalve molluscs. Mar Ecol Prog Ser 36:225-236

Rosón G, Alvarez-Salgado XA, Pérez FF (in press) A nonsteady state box model to determine residual flows in a partially mixed estuary based on both thermohaline properties. Estuar Coast Shelf Sci

Rosón G, Pérez FF, Alvarez-Salgado XA, Figueiras FG (1995) Variation of both thermohaline and chemical properties in an estuarine upwelling ecosystem: Ría de Arousa. I. Temporal evolution. Estuar Coast Shelf Sci 41:195-213

Rosón G, Pérez FF, Alvarez-Salgado XA, Ríos AF (1991) Flujos de los aportes de agua continental a la Ría de Arosa. Scientia Mar 55:583-589

Smaal AC, Prins TC (1993) The uptake of organic matter and the release of inorganic nutrients by bivalve suspension feeder beds. In: Dame RF (ed) Bivalve filter feeders in estuarine and coastal ecosystem processes. NATO ASI Series, G33. Springer-Verlag, Berlin, p 271-298

Smayda TJ, Bienfang PK (1983) Suspension propertıes of various phylletic groups of phytoplankton and tintinnids in an oligotrophic subtropical system. PSZN I: Mar Ecol 4 $289-300$

Smith SV, Veeh HH (1989) Mass balance of biogeochemical active materials (C, N, P) in a hypersaline gulf. Estuar Coast Shelf Sci 29:195-215

Spencer CP (1975) The micronutrient elements. In: Riley JP, Skirrow G (eds) Chemical oceanography, 2nd edn, Vol 2. Academic Press, London, p 245-300

Suzuki T, Matsukawa Y (1987) Hydrography and budget of dissolved total nitrogen and dissolved oxygen in the stratified season in Mikawa Bay, Japan. J Oceanogr Soc Jap $43: 37-48$

Taft JL, Elliott AJ, Taylor WR (1978) Box model analysis of Chesapeake by ammonium and nitrate fluxes. In: Wiley MJ (ed) Estuarine interactions. Academic Press, New York, p 1 15-130

Tenore KR, González N (1975) Food chain patterns in the Ria de Arosa, Spain: an area of intense mussel aquaculture. In Persoone G, Jaspers E (eds) Proc 10th Eur Symp Mar Biol, 
Vol 2, Population dynamics. Universa Press, Wetteren, p $601-619$

Tenore KR and 14 co-authors (1982) Coastal upwelling in the Rias Balxas, NW Spain. Contrasting the benthic regimes of the Ria de Arousa and Muros. J Mar Res 40:701-772

UNESCO (1983) Algorithms for computation of fundamental properties of seawater LINESCO Tech Pap Mar Sci 44

UNESCO (1985) The international system of units (SI) in oceanography. UNESCO Tech Pap Mar Scl 45

Varela JM, Fuentes, Penas E. Cabanas JM (1984) Produccion primaria de las Rías Basxas de Galicia. Actas do primerro seminario de ciencias do mar. As rías galegas. Cuardernos da Area de Ciencias Mariñas. Seminario de Estudos Galegos $1: 137-182$

This article was submitted to the editor
Vitousek PM, Howarth RW (1991) Nitrogen limitation on land and the sea: how can it occur? Biogeochemistry 13: $87-115$

Wada E, Hattori A (1991) Nitrogen in the sea: forms, abundances and rate processes. CRC Press, Boca Raton

Wooster WS, Bakun A, McLain DR (1976) The seasonal upwelling cycle along the eastern boundary of the North Atlantic. J Mar Res 34:131-141

Wroblewskı JS, Hoffmann EE (1989) U.S. interdısciplinary modeling studies of coastal-offshore exchange processes: past and future. Prog Oceanogr 23:65-99

Yentsch C, Menzel W (1963) A method for the determination of phytoplankton, chlorophyll and phaeopigments by fluorescence. Deep Sea Res 10:221-231

Manuscript first received: January 25, 1995

Revised version accepted: November 21, 1995 